\title{
A Case Study: A Process FMEA Tool to Enhance Quality and Efficiency of Manufacturing Industry
}

\author{
Tejaskumar S. Parsana and Mihir T. Patel
}

\begin{abstract}
The study has attempted to present an effective tool for solving the problem of manufacturing process quality by executing process FMEA with proposed process control practices. This paper aims to identify and eliminate current and potential problems from a manufacturing process of cylinder head in the company through the application of Failure Mode and Effects Analysis (FMEA) for improving the reliability of sub systems in order to ensure the quality which in turn enhances the bottom line of a manufacturing industry. Thus the various possible causes of failure and their effects along with the prevention are discussed in this work. Severity values, Occurrence number, Detection and Risk Priority Number (RPN) are some parameters, which need to be determined. Furthermore, some actions are proposed which require to be taken as quickly as possible to avoid potential risks which aid to improve efficiency and effectiveness of cylinder head manufacturing processes and increase the customer satisfaction. The prevention suggested in this paper can considerably decrease the loss to the industry in term of both money time and quality.
\end{abstract}

Keywords--- Cylinder Head, Failure Mode Effect Analysis, Potential Effect of Failure, Potential Failure Mode, Risk Priority Number

\section{INTRODUCTION}

$\mathrm{T}$ HE failure mode and effect analysis is used to identify and analyzed: (1) all failure mode of different parts of the system, (2) effects of these failure mode on the system and (3) how to circumvent the failure and/or moderate the effect of the failure system. FMEA is a step by step tactic to identifying all possible failure throughout the processes. "Effect Analysis" denotes to studying the consequences of those failures [12]. The motivation for undertaking a Process FMEA is to continually develop products and process consistency thereby increasing customer satisfaction [8].

The FMEA was developed and implemented for the first time in 1949 by U.S. Army and later executed in Apollo space programme to temperate the risk [5]. FMEA is a very significant method which should be engaged in companies for

Tejaskumar S. Parsana, Post Graduate Scholar, Industrial Engineering, G. H. Patel College of Engineering \& Technology, Gujarat, India. Email:tejas.parsana@gmail.com

Mihir T. Patel, Lecturer, Department of Mechanical Engineering, B \& B Institute of Technology, Gujarat, India. E-mail:mihireagle@yahoo.com

DOI: 10.9756/BIJIEMS.10350 an engineering design, production process and new product in planning and production sphere in product life cycle. Purpose of FMEA is founding links between causes and effects of defects, as well as searching, solving and drawing the best decisions regarding solicitation of applicable action.

\section{LiteratURE REVIEW}

In 1950s the increasing attention paid to safety and the need to prevent predictable accidents in aerospace industry led to the development of the FMEA methodology. Later, it was introduced as key tool for increasing quality and efficiency in manufacturing processes [10]. In 1977, Ford Motors introduced FMEA to address the potential problems in the Research and Development (R\&D) in the early stage of production and published the Potential Failure Mode and Effects Analysis Handbook in 1984 to promote the method. Later on the automobile manufacturers in America also introduced the FMEA into the management of suppliers, and took it as a key check issue [13]. Find out reasons behind the failure of some subjects of mechanical engineering course and after analyzed the system through FMEA and they suggested recommend to solve the problem [15]. Execute FMEA to develop an effective quality system and to improve the current production processfor the better quality of the products [14]. Applied FMEA model in salmon processing and packing industry in joint with ISO 22000 and they got the valuable result from implementation [7].The FMEA has the potential to improve the reliability of Wind turbine systems especially for the offshore environment and made system cost effective [3]. Modified failure mode and effects analysis (MFMEA) method to select new suppliers in term the supply chain risk's perspective and applies the analytic hierarchy process method and found excellent result [11]. Applied FMEA technique on two products flywheel and flywheel housing and prevent different failure mode and suggestions were successfully implemented and the industry gained considerably in terms of both money and time [4]. Used FMEA to optimize the decision making process in new product development in automobile industry [2]. Implemented FMEA at the design stage As such, they could be compared with Failure Reporting, Analysis and Corrective Action System results once actual failures are observed during test, production and operation. They recommended taking appropriate actions to avoid possibility [1].

\section{CONCEPT OF FMEA}

Failure mode and effect analysis is an analytical technique (a paper test) that combines technology and experience of people in identifying probable failure mode of product or 
process and planning for its abolition. FMEA is a "before-theevent" action requiring a team effort to easily and inexpensively alleviate changes in design and production.

FMEA can be explained as a group of events projected to

- Recognize and evaluate the potential failure of a product or process and its effects.

- Identify actions that could eliminate or reduce the chance of potential failures.

- Document the process.

FMEA can be used as an individual project tool. However, it is strongly recommended that use to generate corrective action in a process improvement project. An FMEA is not a trivial tool rather it requires significant effort from a diverse team.

FMEA method use at [9]:

- Formation of the product concept, for checking whether all prospects of the customer are included in this concept.

- Define the product, in order to check whether projects, service, supplies are appropriate and controlled in the right time.

- Process of production, in order to check whether documentation primed by engineers is fully carried out.

- Assembly, for checking whether the process of the assembly is compatible with documentation.

- Organization of the service, in order to check whether the product or the service is pleasant with recognized criteria.

\section{DOCUMENTATION PROCEDURE FOR FMEA}

\section{A. Item and its Functions}

Specify all the functions of an item, including the environment in which it has to operate.

\section{B. Potential Failure Mode}

- Considering past failures, present reports, brainstorming.

- Describe in technical terms and not as customers will see.

- For e.g. cracked, deformed, loosened, short circuited, fractured, leaking, sticking, oxidized etc.

\section{Potential Effects of Failure}

- As perceived by the customer (internal/end user).

- For e.g. erratic operation, poor appearance, noise, impaired functions, deterioration etc.

\section{Severity}

Severity is the assessment of the seriousness of the effect of the potential failure mode. In this we have to determine all failure modes based on the functional requirements and their effects. An example table of severity is given below.
Table 1: Table of Severity

\begin{tabular}{|c|c|c|}
\hline Code & Classification & Example \\
\hline 10 & $\begin{array}{l}\text { Hazardous } \\
\text { Without } \\
\text { Warning }\end{array}$ & $\begin{array}{l}\text { Very High Ranking - Affecting } \\
\text { safe operation. }\end{array}$ \\
\hline 9 & $\begin{array}{l}\text { Hazardous With } \\
\text { Warning }\end{array}$ & Regulatory non compliance \\
\hline 8 & Very High & $\begin{array}{l}\text { Product becomes inoperable, with } \\
\text { loss of function - Customer Very } \\
\text { Much Dissatisfied }\end{array}$ \\
\hline 7 & High & $\begin{array}{c}\text { Product remain operable but loss of } \\
\text { performance - Customer } \\
\text { Dissatisfied }\end{array}$ \\
\hline 6 & Moderate & $\begin{array}{c}\text { Product remain operable but loss of } \\
\text { comfort/convenience - Customer } \\
\text { Discomfort }\end{array}$ \\
\hline 5 & Low & $\begin{array}{c}\text { Product remain operable but loss of } \\
\text { comfort/convenience - Customer } \\
\text { Slightly Dissatisfied }\end{array}$ \\
\hline 4 & Very Low & $\begin{array}{l}\text { Nonconformance by certain items } \\
\text { - Noticed by most customers }\end{array}$ \\
\hline 3 & Minor & $\begin{array}{l}\text { Nonconformance by certain items } \\
\text { - Noticed by average customers }\end{array}$ \\
\hline 2 & Very Minor & $\begin{array}{l}\text { Nonconformance by certain items } \\
\text { - Noticed by selective customers }\end{array}$ \\
\hline 1 & None & No Effect \\
\hline
\end{tabular}

E. Class

Classification of any special product characteristics requiring additional process control

\section{F. Potential Cause /Mechanism of Failure}

Every cause/mechanism must be listed concisely

- E.g. of Failure Causes are inadequate design, incorrect material, inaccurate life assumption, poor environmental protection, over stressing, insufficient lubrication etc.

- E.g. of Failure Mechanisms are fatigue, wear, corrosion, yield, creep etc.

\section{G. Occurrence}

Occurrence is the chance that one of the specific cause/mechanism will occur. In this step, it is necessary to look at the cause of a failure and how many times it occurs. Looking at similar products or processes and the failures that have been documented for them can do this. A failure cause is looked upon as a design weakness. An example for occurrence rating is given in following table.

Table 2: Table of Occurrence

\begin{tabular}{|c|c|c|}
\hline Code & Classification & Example \\
\hline 10 and 9 & Very High & Inevitable Failure \\
\hline 8 and 7 & High & Repeated Failures \\
\hline 6 and 5 & Moderate & Occasional Failures \\
\hline 4,3 and 2 & Low & Few Failures \\
\hline 1 & Remote & Failure Unlikely \\
\hline
\end{tabular}




\section{H. Current Design Control}

The control activities generally include Prevention Measures, Design Validation, and Design Verification Supported by physical tests, mathematical modeling, prototype testing, and feasibility reviews etc.

\section{Detection}

- Relative measures of the ability of design control to detect wither a potential cause/mechanism or the subsequent failure mode before production.

- Supported by physical tests, mathematical modeling, prototype testing, feasibility reviews etc.

Table 3: Table of Detection

\begin{tabular}{|c|c|c|}
\hline Detection & Rank & Criteria \\
\hline $\begin{array}{l}\text { Extremely } \\
\text { Likely }\end{array}$ & 1 & $\begin{array}{c}\text { Can be corrected prior to } \\
\text { prototype/ Controls will almost } \\
\text { certainly detect }\end{array}$ \\
\hline $\begin{array}{l}\text { Very High } \\
\text { Likelihood }\end{array}$ & 2 & $\begin{array}{l}\text { Can be corrected prior to design } \\
\text { release/Very High probability of } \\
\text { detection }\end{array}$ \\
\hline $\begin{array}{c}\text { High } \\
\text { Likelihood }\end{array}$ & 3 & $\begin{array}{l}\text { Likely to be corrected/High } \\
\text { probability of detection }\end{array}$ \\
\hline $\begin{array}{l}\text { Moderately } \\
\text { High } \\
\text { Likelihood } \\
\end{array}$ & 4 & $\begin{array}{l}\text { Design controls are moderately } \\
\text { effective }\end{array}$ \\
\hline $\begin{array}{c}\text { Medium } \\
\text { Likelihood }\end{array}$ & 5 & $\begin{array}{l}\text { Design controls have an even } \\
\text { chance of working }\end{array}$ \\
\hline $\begin{array}{l}\text { Moderately } \\
\text { Low } \\
\text { Likelihood } \\
\end{array}$ & 6 & $\begin{array}{l}\text { Design controls may miss the } \\
\text { problem }\end{array}$ \\
\hline $\begin{array}{c}\text { Low } \\
\text { Likelihood }\end{array}$ & 7 & $\begin{array}{c}\text { Design controls are likely to miss } \\
\text { the problem }\end{array}$ \\
\hline $\begin{array}{l}\text { Very Low } \\
\text { Likelihood }\end{array}$ & 8 & $\begin{array}{l}\text { Design controls have a poor } \\
\text { chance of detection }\end{array}$ \\
\hline $\begin{array}{l}\text { Very Low } \\
\text { Likelihood }\end{array}$ & 9 & $\begin{array}{l}\text { Unproven, unreliable design/poor } \\
\text { chance for detection }\end{array}$ \\
\hline $\begin{array}{c}\text { Extremely } \\
\text { Unlikely }\end{array}$ & 10 & $\begin{array}{c}\text { No design technique } \\
\text { available/Controls will not detect }\end{array}$ \\
\hline
\end{tabular}

\section{J. $\quad$ Risk Priority Numbers (RPN)}

RPN is the indicator for the determining proper corrective action on the failure modes. It is calculated by multiplying the severity, occurrence and detection ranking levels resulting in a scale from 1 to 1000.After deciding the severity, occurrence and detection numbers, the RPN can be easily calculated by multiplying these 3 numbers: $R P N=$ Severity $\times$ Occurrence $\times$ Detection. The small RPN is always better than the high RPN. The RPN can be computed for the entire process and/or for the design process only. Once it is calculated, it is easy to determine the areas of greatest concern. The engineering team generates the RPN and focused to the solution of failure modes.

\section{K. Recommended Actions} order

Beginning with high RPN and working in descending

- The objective is to reduce one or more of the criteria that make up the RPN.
- Typical actions are design of experiments, revised test plans, revised material specifications, revised design etc.

- Important to mark "None" in case of no recommendation for future use of FMEA document.

\section{Responsibilities and Completion Dates}

Individual or group responsible for the recommended actions and target completion date to be entered.

\section{Actions Taken}

Brief descriptions of the action taken to be entered after actual actions are taken by the team.

\section{N. Revised RPN}

Recalculation of Severity, Occurrence and Detection rankings after implementation of recommended actions and thus calculation of revised RPN.

Revised RPN=revised (Severity $\times$ Occurrence $\times$ Detection)

\section{FMEA PROCEDURE [6]}

The process for conducting FMEA can be divided into following steps. These steps are briefly explained as follows.

- Step 1: Collect the functions of system and build a hierarchical structure. Divide the system into several subsystems, having number of components.

- Step 2: Determine the failure modes of each component and its effects. Assign the severity rating (S) of each failure mode according to the respective effects on the system.

- Step 3: Determine the causes of failure modes and estimate the likelihood of each failure occurring. Assign the occurrence rating $(\mathrm{O})$ of each failure mode according to its likelihood of occurrence.

- Step 4: List the approaches to detect the failures and evaluate the ability of system to detect the failures prior to the failures occurring. Assign the detection rating (D) of each failure mode.

- Step 5: Calculate the risk priority number (RPN) and establish the priorities for attention.

- Step 6: Take recommended actions to enrich the performance of system.

- Step 7: Conduct FMEA report in a tabular form.

\section{CASE STUDY AND FMEA ANALYSIS}

A cylinder head is the closed, and often detachable, end of a cylinder located in an internal combustion engine. It is typically found on the top portion of the engine block as shown in Figure 1. 


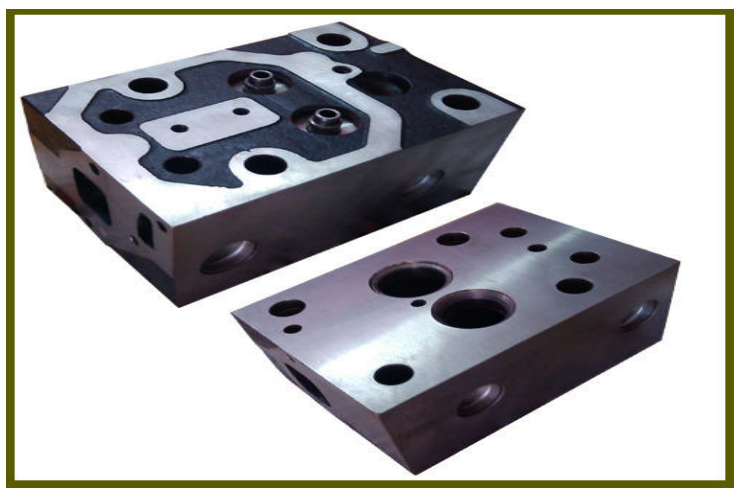

The cylinder head is an integral component of internal combustion engines. It conveys air and gasoline to the combustion chamber and serves as a cover for the cylinders. The main function of the cylinder head is to help the head gasket seal the cylinders properly so that they are able to build enough compression for engine operation.

In the vast majority of four stroke engines, the cylinder head mounts the entire valve gear and provides the basic framework for housing the valves as well as the spark plugs and injectors.

Case study is conducted and FMEA technique is applied to the cylinder head manufacturing process industry. There are various operation and processes carried out by various machine for manufacturing cylinder head. Facing, drilling and tapping are the main manufacturing operations of the cylinder head. Following manufacturing operations are carried out on the cylinder head:

- Bottom Face Finish

- Top Face Finish

- Inlet \& Exhaust face finish
Figure 1: Cylinder Head

- Front \& rear side face finish

- Top Side

- $\quad$ Bottom Side

- $\quad$ Inlet \& Exhaust face Drilling

- Water Outlet Face Drilling

- Core Plug Drilling

- Injector Bore etc.

Criteria for ranking of severity occurrence and detection are selected suitably by analyzing the past failure records of the machine. Firstly, the basic requirements of the manufacturing processes are studied and then the potential failure mode of the specific process is found out. After that the potential effects of the failure mode are noted with their severity value. The occurrence value for the potential causes and their prevention is also calculated. The Detection value is assigned to the failure mode and finally the R.P.N value is calculated. The sample calculations are if $\mathrm{S}=4, \mathrm{O}=3, \& \mathrm{D}=4$

Then, R.P.N $=\mathrm{S} \times \mathrm{O} \times \mathrm{D}=4 \times 3 \times 4=48$

FMEA Chart of Cylinder head is shown in Table 4.

Table 4: Process FMEA

\begin{tabular}{|c|c|c|c|c|c|c|c|c|c|c|}
\hline \multicolumn{11}{|c|}{ PROCESS FAILURE MODE AND EFFECT ANALYSIS } \\
\hline \multicolumn{5}{|c|}{ Part / Product No. : X-Cylinder Head } & \multicolumn{3}{|c|}{ Key Contact Person :*** } & \multicolumn{3}{|c|}{ Doc. No. : X/FMEA/** } \\
\hline \multicolumn{5}{|c|}{ Part / Product Description : Engine Cylinder Head } & \multicolumn{3}{|c|}{ Key Contact : **** } & \multicolumn{3}{|c|}{ Rev. No. : } \\
\hline \multicolumn{5}{|c|}{ Customer Name (If any) : *** } & \multicolumn{3}{|c|}{ Core Team : **** } & \multicolumn{3}{|c|}{ Revision Date } \\
\hline \multicolumn{11}{|c|}{ Customer Drawing No. (If any) : *** } \\
\hline \multicolumn{5}{|c|}{ Other Details (if any) : } & & & & & & \\
\hline $\begin{array}{l}\text { Operation } \\
\text { No. }\end{array}$ & $\begin{array}{c}\text { Process } \\
\text { Description }\end{array}$ & $\begin{array}{c}\text { Potential } \\
\text { Failure Mode }\end{array}$ & $\begin{array}{l}\text { Potential } \\
\text { Effect of } \\
\text { Failure }\end{array}$ & SEV. & $\begin{array}{l}\text { Potential } \\
\text { Causes }\end{array}$ & OCC. & $\begin{array}{c}\text { Current } \\
\text { Control } \\
\text { Prevention }\end{array}$ & $\begin{array}{c}\text { Current } \\
\text { Control } \\
\text { Detection }\end{array}$ & DET. & RPN \\
\hline \multirow[t]{2}{*}{1} & \multirow{2}{*}{$\begin{array}{l}\text { Bottom } \\
\text { Face Finish }\end{array}$} & $\begin{array}{c}\text { Height } \pm \\
\text { then } \\
\text { specification }\end{array}$ & $\begin{array}{c}\text { Smoke } \\
\text { problem, Fuel } \\
\text { problem }\end{array}$ & 6 & $\begin{array}{l}\text { Improper } \\
\text { Setting, } \\
\text { Improper } \\
\text { material } \\
\text { removal }\end{array}$ & 2 & \multirow{2}{*}{$\begin{array}{c}\text { Process } \\
\text { drawing, } \\
\text { work } \\
\text { instruction, } \\
\text { first piece } \\
\text { inspection }\end{array}$} & $\begin{array}{c}\text { Inprocess } \\
\text { inspection } \\
\text { (inspect } 1 \\
\text { after 5) }\end{array}$ & 3 & 36 \\
\hline & & $\begin{array}{l}\text { Flatness out } \\
\text { of } \\
\text { specification }\end{array}$ & $\begin{array}{c}\text { Fitment } \\
\text { problem \& } \\
\text { functional } \\
\text { problem }\end{array}$ & 6 & $\begin{array}{c}\text { Improper } \\
\text { setting, } \\
\text { Improper tool } \\
\text { select }\end{array}$ & 2 & & $\begin{array}{c}100 \% \\
\text { inspection }\end{array}$ & 1 & 12 \\
\hline \multirow[t]{2}{*}{2} & \multirow{2}{*}{$\begin{array}{l}\text { Top Face } \\
\text { Finish }\end{array}$} & $\begin{array}{l}\text { Height } \pm \\
\text { then } \\
\text { specification }\end{array}$ & $\begin{array}{l}\text { Oil leakage } \\
\text { problem, } \\
\text { Function } \\
\text { problem at } \\
\text { customer end }\end{array}$ & 6 & $\begin{array}{l}\text { Improper } \\
\text { Setting, } \\
\text { Improper } \\
\text { material } \\
\text { removal }\end{array}$ & 2 & \multirow{2}{*}{$\begin{array}{c}\text { Process } \\
\text { drawing, } \\
\text { work } \\
\text { instruction, } \\
\text { first piece } \\
\text { inspection }\end{array}$} & $\begin{array}{c}\text { Inprocess } \\
\text { inspection } \\
\text { (inspect } 1 \\
\text { after 5) }\end{array}$ & 3 & 36 \\
\hline & & $\begin{array}{l}\text { Flatness out } \\
\text { of } \\
\text { specification }\end{array}$ & $\begin{array}{c}\text { Fitment } \\
\text { problem \& } \\
\text { functional } \\
\text { problem }\end{array}$ & & $\begin{array}{c}\text { Improper } \\
\text { setting, } \\
\text { Improper tool } \\
\text { select }\end{array}$ & 2 & & $\begin{array}{c}100 \% \\
\text { inspection }\end{array}$ & 1 & 12 \\
\hline
\end{tabular}




\begin{tabular}{|c|c|c|c|c|c|c|c|c|c|c|}
\hline 3 & $\begin{array}{l}\text { Dowel hole } \\
\text { semi finish, } \\
\text { bottom side }\end{array}$ & $\begin{array}{c}\text { Drill Dia. } \\
\text { And depth } \pm \\
\text { then } \\
\text { specification }\end{array}$ & $\begin{array}{c}\text { Fitment } \\
\text { problem \& } \\
\text { functional } \\
\text { problem at } \\
\text { later } \\
\text { stage(internal) }\end{array}$ & 6 & $\begin{array}{c}\text { Improper } \\
\text { setting, } \\
\text { Improper tool } \\
\text { select }\end{array}$ & 2 & $\begin{array}{c}\text { Process } \\
\text { drawing, } \\
\text { work } \\
\text { instruction, } \\
\text { first piece } \\
\text { inspection }\end{array}$ & $\begin{array}{c}100 \% \\
\text { inspection }\end{array}$ & 1 & 12 \\
\hline \multirow[t]{2}{*}{4} & \multirow{2}{*}{$\begin{array}{c}\text { Inlet \& } \\
\text { Exhaust } \\
\text { face finish }\end{array}$} & $\begin{array}{c}\text { Height } \pm \\
\text { then } \\
\text { specification }\end{array}$ & $\begin{array}{c}\text { Subsequent } \\
\text { operation } \\
\text { problem, } \\
\text { functional } \\
\text { problem at } \\
\text { customer end }\end{array}$ & 6 & $\begin{array}{l}\text { Improper } \\
\text { Setting, } \\
\text { Improper } \\
\text { material } \\
\text { removal }\end{array}$ & 2 & \multirow{2}{*}{$\begin{array}{l}\text { Process } \\
\text { drawing, } \\
\text { work } \\
\text { instruction, } \\
\text { first piece } \\
\text { inspection }\end{array}$} & $\begin{array}{l}\text { Inprocess } \\
\text { inspection } \\
\text { (inspect } 1 \\
\text { after } 5 \text { ) }\end{array}$ & 3 & 36 \\
\hline & & $\begin{array}{c}\text { Flatness out } \\
\text { of } \\
\text { specification }\end{array}$ & $\begin{array}{c}\text { Fitment } \\
\text { problem \& } \\
\text { functional } \\
\text { problem at } \\
\text { later } \\
\text { stage(internal) }\end{array}$ & 6 & $\begin{array}{c}\text { Improper } \\
\text { setting, } \\
\text { Improper tool } \\
\text { select }\end{array}$ & 2 & & $\begin{array}{c}100 \% \\
\text { inspection }\end{array}$ & 1 & 12 \\
\hline \multirow[t]{2}{*}{5} & \multirow{2}{*}{$\begin{array}{l}\text { Front \& rear } \\
\text { side face } \\
\text { finish }\end{array}$} & $\begin{array}{c}\text { Height } \pm \\
\text { then } \\
\text { specification }\end{array}$ & $\begin{array}{c}\text { Subsequent } \\
\text { operation } \\
\text { problem, } \\
\text { functional } \\
\text { problem at } \\
\text { customer end }\end{array}$ & 6 & $\begin{array}{l}\text { Improper } \\
\text { Setting, } \\
\text { Improper } \\
\text { material } \\
\text { removal }\end{array}$ & 2 & \multirow{2}{*}{$\begin{array}{c}\text { Process } \\
\text { drawing, } \\
\text { work } \\
\text { instruction, } \\
\text { first piece } \\
\text { inspection }\end{array}$} & $\begin{array}{l}\text { Inprocess } \\
\text { inspection } \\
\text { (inspect } 1 \\
\text { after } 5 \text { ) }\end{array}$ & 3 & 36 \\
\hline & & $\begin{array}{c}\text { Flatness out } \\
\text { of } \\
\text { specification }\end{array}$ & $\begin{array}{c}\text { Fitment } \\
\text { problem \& } \\
\text { functional } \\
\text { problem at } \\
\text { later } \\
\text { stage(internal) }\end{array}$ & 6 & $\begin{array}{c}\text { Improper } \\
\text { setting, } \\
\text { Improper tool } \\
\text { select }\end{array}$ & 2 & & $\begin{array}{c}100 \% \\
\text { inspection }\end{array}$ & 1 & 12 \\
\hline \multirow{4}{*}{$\begin{array}{l}6 \text { (Top } \\
\text { Side) }\end{array}$} & $\begin{array}{l}\text { Top side } \\
\text { dowel hole } \\
\text { finish }\end{array}$ & $\begin{array}{c}\text { Drill Dia. } \\
\text { And depth } \pm \\
\text { then } \\
\text { specification }\end{array}$ & $\begin{array}{c}\text { Fitment } \\
\text { problem \& } \\
\text { functional } \\
\text { problem at } \\
\text { customer end }\end{array}$ & \multirow{4}{*}{6} & \multirow{4}{*}{$\begin{array}{l}\text { Improper } \\
\text { setting, tool } \\
\text { wear, } \\
\text { improper } \\
\text { process } \\
\text { parameters }\end{array}$} & \multirow{4}{*}{2} & \multirow{4}{*}{$\begin{array}{l}\text { Setup VMC } \\
\text { program, } \\
\text { process } \\
\text { drawing, } \\
\text { work } \\
\text { instruction, } \\
\text { first piece } \\
\text { inspection }\end{array}$} & \multirow{4}{*}{$\begin{array}{l}\text { Inprocess } \\
\text { inspection }\end{array}$} & \multirow{4}{*}{3} & \multirow{4}{*}{36} \\
\hline & $\begin{array}{l}\text { Top side } \\
\text { bolt hole } \\
\text { finish }\end{array}$ & $\begin{array}{c}\text { Drill Dia. } \\
\text { And depth } \pm \\
\text { then } \\
\text { specification }\end{array}$ & $\begin{array}{c}\text { Fitment } \\
\text { problem \& } \\
\text { functional } \\
\text { problem at } \\
\text { customer end }\end{array}$ & & & & & & & \\
\hline & $\begin{array}{c}\text { Rocker } \\
\text { mounting } \\
\text { hole }\end{array}$ & $\begin{array}{c}\text { Drill Dia. } \\
\text { And depth } \pm \\
\text { then } \\
\text { specification }\end{array}$ & $\begin{array}{c}\text { Functional } \\
\text { problem at } \\
\text { customer end }\end{array}$ & & & & & & & \\
\hline & Spot face & $\begin{array}{c}\text { Drill Dia. } \\
\text { And depth } \pm \\
\text { then } \\
\text { specification }\end{array}$ & $\begin{array}{c}\text { Functional } \\
\text { problem at } \\
\text { customer end }\end{array}$ & & & & & & & \\
\hline \multirow{4}{*}{$\begin{array}{c}7 \\
\text { (Bottom } \\
\text { Side) }\end{array}$} & $\begin{array}{l}\text { Bolt Hole } \\
\text { finish }\end{array}$ & $\begin{array}{c}\text { Drill Dia. } \\
\text { And depth } \pm \\
\text { then } \\
\text { specification }\end{array}$ & \multirow{3}{*}{$\begin{array}{c}\text { Fitment } \\
\text { problem \& } \\
\text { functional } \\
\text { problem at } \\
\text { customer end }\end{array}$} & 6 & \multirow{3}{*}{$\begin{array}{c}\text { Improper } \\
\text { setting, tool } \\
\text { wear, } \\
\text { improper } \\
\text { process } \\
\text { parameters }\end{array}$} & 2 & \multirow{4}{*}{$\begin{array}{l}\text { Setup VMC } \\
\text { program, } \\
\text { process } \\
\text { drawing, } \\
\text { work } \\
\text { instruction, } \\
\text { first piece } \\
\text { inspection }\end{array}$} & \multirow{3}{*}{$\begin{array}{l}\text { Inprocess } \\
\text { Inspection }\end{array}$} & 3 & 36 \\
\hline & $\begin{array}{l}\text { Dowel } \\
\text { finish }\end{array}$ & $\begin{array}{c}\text { Drill Dia. } \\
\text { And depth } \pm \\
\text { then } \\
\text { specification }\end{array}$ & & 6 & & 2 & & & 3 & 36 \\
\hline & $\begin{array}{l}\text { Push rod } \\
\text { Hole }\end{array}$ & $\begin{array}{c}\text { Drill Dia. } \\
\text { And depth } \pm \\
\text { then } \\
\text { specification }\end{array}$ & & 2 & & 2 & & & 3 & 12 \\
\hline & $\begin{array}{c}\text { Valve guide } \\
\text { Hole }\end{array}$ & $\begin{array}{c}\text { Drill Dia. } \\
\text { And depth } \pm \\
\text { then } \\
\text { specification }\end{array}$ & $\begin{array}{c}\text { Fitment } \\
\text { problem \& } \\
\text { functional } \\
\text { problem at }\end{array}$ & 6 & $\begin{array}{c}\text { Improper } \\
\text { setting, tool } \\
\text { wear, } \\
\text { improper }\end{array}$ & 2 & & $\begin{array}{c}\text { In process } \\
\text { inspection } \\
(100 \%)\end{array}$ & 3 & 36 \\
\hline
\end{tabular}




\begin{tabular}{|c|c|c|c|c|c|c|c|c|c|c|}
\hline & & & customer end & & $\begin{array}{c}\text { process } \\
\text { parameters }\end{array}$ & & & & & \\
\hline & $\begin{array}{l}\text { Valve seat } \\
\text { Bore }\end{array}$ & $\begin{array}{c}\text { Drill Dia. } \\
\text { And depth } \pm \\
\text { then } \\
\text { specification }\end{array}$ & $\begin{array}{c}\text { Fitment } \\
\text { problem \& } \\
\text { functional } \\
\text { problem at } \\
\text { customer end }\end{array}$ & 4 & $\begin{array}{c}\text { Improper } \\
\text { setting, } \\
\text { improper Tool } \\
\text { select }\end{array}$ & 2 & & $\begin{array}{l}\text { Inprocess } \\
\text { Inspection }\end{array}$ & 3 & 24 \\
\hline & $\begin{array}{c}\text { Water } \\
\text { Direction } \\
\text { Hole }\end{array}$ & $\begin{array}{l}\text { Drill Dia. } \\
\text { And depth } \pm \\
\text { then } \\
\text { specification }\end{array}$ & $\begin{array}{l}\text { Leakage } \\
\text { Problem }\end{array}$ & 6 & $\begin{array}{c}\text { Improper } \\
\text { setting, } \\
\text { improper Tool } \\
\text { select } \\
\end{array}$ & 2 & & $\begin{array}{l}\text { Inprocess } \\
\text { Inspection }\end{array}$ & 3 & 36 \\
\hline 8 & $\begin{array}{c}\text { Inlet \& } \\
\text { Exhaust } \\
\text { face } \\
\text { Drilling }\end{array}$ & $\begin{array}{l}\text { Drill Dia. } \\
\text { And depth } \pm \\
\text { then } \\
\text { specification }\end{array}$ & $\begin{array}{l}\text { Functional } \\
\text { Problem In } \\
\text { Tapping }\end{array}$ & 6 & $\begin{array}{c}\text { Improper } \\
\text { setting, tool } \\
\text { wear, } \\
\text { improper } \\
\text { process } \\
\text { parameters }\end{array}$ & 2 & $\begin{array}{c}\text { Process } \\
\text { drawing, } \\
\text { work } \\
\text { instruction, } \\
\text { first piece } \\
\text { inspection }\end{array}$ & $\begin{array}{l}\text { In process } \\
\text { inspection } \\
(100 \%)\end{array}$ & 1 & 12 \\
\hline 9 & $\begin{array}{c}\text { Water } \\
\text { Outlet Face } \\
\text { Drilling }\end{array}$ & $\begin{array}{l}\text { Drill Dia. } \\
\text { And depth } \pm \\
\text { then } \\
\text { specification }\end{array}$ & $\begin{array}{l}\text { Functional } \\
\text { Problem In } \\
\text { Tapping }\end{array}$ & 6 & $\begin{array}{c}\text { Improper } \\
\text { setting, tool } \\
\text { wear, } \\
\text { improper } \\
\text { process } \\
\text { parameters }\end{array}$ & 2 & $\begin{array}{c}\text { Process } \\
\text { drawing, } \\
\text { work } \\
\text { instruction, } \\
\text { first piece } \\
\text { inspection } \\
\end{array}$ & $\begin{array}{l}\text { In process } \\
\text { inspection } \\
(100 \%)\end{array}$ & 1 & 12 \\
\hline 10 & $\begin{array}{l}\text { Core Plug } \\
\text { Drilling }\end{array}$ & $\begin{array}{l}\text { Drill Dia. } \\
\text { And depth } \pm \\
\text { then } \\
\text { specification }\end{array}$ & $\begin{array}{c}\text { Fitment } \\
\text { Problem \& } \\
\text { Leakage } \\
\text { Problem }\end{array}$ & 6 & $\begin{array}{c}\text { Improper } \\
\text { setting, } \\
\text { improper Tool } \\
\text { select }\end{array}$ & 2 & $\begin{array}{c}\text { Process } \\
\text { drawing, } \\
\text { work } \\
\text { instruction, } \\
\text { first piece } \\
\text { inspection }\end{array}$ & $\begin{array}{l}\text { Inprocess } \\
\text { Inspection }\end{array}$ & 2 & 24 \\
\hline \multirow{7}{*}{11} & \multirow{7}{*}{$\begin{array}{l}\text { Injector } \\
\text { Bore }\end{array}$} & $\begin{array}{c}\text { Nozzle Bore } \\
\text { Plus }\end{array}$ & loose Fitment & 6 & \multirow{2}{*}{$\begin{array}{l}\text { Manual } \\
\text { Boring } \\
\text { Control On } \\
\text { Reading }\end{array}$} & 2 & \multirow{2}{*}{$\begin{array}{c}\text { Process } \\
\text { drawing, } \\
\text { work } \\
\text { instruction, } \\
\text { first piece } \\
\text { inspection }\end{array}$} & \multirow{2}{*}{$\begin{array}{l}\text { Inprocess } \\
\text { Inspection }\end{array}$} & 3 & 36 \\
\hline & & $\begin{array}{c}\text { Nozzle Bore } \\
\text { Minus }\end{array}$ & No Fitment & 6 & & 2 & & & 3 & 36 \\
\hline & & $\begin{array}{c}\text { Nozzle Step } \\
\text { Bore Plus }\end{array}$ & loose Fitment & 6 & \multirow{2}{*}{$\begin{array}{l}\text { Manual } \\
\text { Boring } \\
\text { Control On } \\
\text { Reading }\end{array}$} & 2 & \multirow{2}{*}{$\begin{array}{c}\text { Process } \\
\text { drawing, } \\
\text { work } \\
\text { instruction, } \\
\text { first piece } \\
\text { inspection }\end{array}$} & \multirow[b]{2}{*}{$\begin{array}{l}\text { Inprocess } \\
\text { Inspection }\end{array}$} & 2 & 24 \\
\hline & & $\begin{array}{l}\text { Nozzle Step } \\
\text { Bore Minus }\end{array}$ & No Fitment & 6 & & 2 & & & 2 & 24 \\
\hline & & $\begin{array}{c}\text { Nozzle Bore } \\
\text { Depth Plus }\end{array}$ & $\begin{array}{c}\text { Injection } \\
\text { Point/Position } \\
\text { Changes Can } \\
\text { Lead High } \\
\text { Fuel } \\
\text { Consumption }\end{array}$ & 6 & $\begin{array}{c}\text { Stopper } \\
\text { Resting Face } \\
\text { Is Uneven Or } \\
\text { Containment } \\
\text { In Between } \\
\text { Control Face }\end{array}$ & 3 & \multirow{2}{*}{$\begin{array}{c}\text { Process } \\
\text { drawing, } \\
\text { work } \\
\text { instruction, } \\
\text { Master } \\
\text { piece of } \\
\text { Correct } \\
\text { Depth is } \\
\text { Provide For } \\
\text { Setting, }\end{array}$} & \multirow{2}{*}{$\begin{array}{l}\text { In process } \\
\text { inspection } \\
(100 \%)\end{array}$} & 3 & 54 \\
\hline & & $\begin{array}{l}\text { Nozzle Bore } \\
\text { Depth Minus }\end{array}$ & $\begin{array}{c}\text { Knocking } \\
\text { Effect \& Effect } \\
\text { On Fuel } \\
\text { Consumption }\end{array}$ & 6 & $\begin{array}{c}\text { Excess Wear } \\
\text { out of Valve } \\
\text { Guide } \\
\text { Locking Pins }\end{array}$ & 3 & & & 2 & 36 \\
\hline & & $\begin{array}{c}\text { Concentricity } \\
\text { of Both Bores } \\
\text { Not Ok }\end{array}$ & No Fitment & 6 & $\begin{array}{c}\text { Inpositioning } \\
\text { Boring }\end{array}$ & 2 & $\begin{array}{c}\text { Process } \\
\text { drawing, } \\
\text { work } \\
\text { instruction } \\
\end{array}$ & $\begin{array}{l}\text { In process } \\
\text { inspection } \\
(100 \%)\end{array}$ & 2 & 24 \\
\hline 12 & $\begin{array}{c}\text { Hole } \\
\text { Chamfering }\end{array}$ & Burr Inside & $\begin{array}{c}\text { Handling \& } \\
\text { Fitment } \\
\text { Problem }\end{array}$ & 8 & $\begin{array}{l}\text { Improper } \\
\text { Tool, File } \\
\text { Selected }\end{array}$ & 2 & $\begin{array}{c}\text { Process } \\
\text { drawing, } \\
\text { work } \\
\text { instruction, } \\
\text { first piece } \\
\text { inspection } \\
\end{array}$ & $\begin{array}{l}\text { Inprocess } \\
\text { Inspection }\end{array}$ & 1 & 16 \\
\hline 13 & Tapping & $\begin{array}{c}\text { Tapping } \\
\text { depth } \pm \text { then }\end{array}$ & $\begin{array}{l}\text { Functional } \\
\text { problem at }\end{array}$ & 6 & $\begin{array}{c}\text { Improper } \\
\text { setting, tool }\end{array}$ & 2 & $\begin{array}{l}\text { Process } \\
\text { drawing, }\end{array}$ & $\begin{array}{c}100 \% \\
\text { inspection }\end{array}$ & 1 & 12 \\
\hline
\end{tabular}




\begin{tabular}{|c|c|c|c|c|c|c|c|c|c|c|}
\hline & & specification & customer end & & $\begin{array}{c}\text { wear, Jig bush } \\
\text { Wear out }\end{array}$ & & $\begin{array}{c}\text { work } \\
\text { instruction, } \\
\text { first piece } \\
\text { inspection }\end{array}$ & & & \\
\hline 15 & Air Testing & $\begin{array}{c}\text { Air Pressure } \\
\text { \& Leakage } \\
\text { Test }\end{array}$ & $\begin{array}{c}\text { Leakage } \\
\text { Problem at } \\
\text { customer End }\end{array}$ & 8 & $\begin{array}{c}\text { Improper } \\
\text { Leakage } \\
\text { Testing }\end{array}$ & 2 & $\begin{array}{c}\text { work } \\
\text { Instruction }\end{array}$ & $\begin{array}{c}100 \% \\
\text { Inspection }\end{array}$ & 1 & 16 \\
\hline 16 & $\begin{array}{c}\text { Valve seat } \\
\text { Cutting } \\
\text { Inlet }\end{array}$ & $\begin{array}{l}\text { Depth } \pm \text { then } \\
\text { specification }\end{array}$ & $\begin{array}{c}\text { Leakage } \\
\text { Problem at } \\
\text { customer End }\end{array}$ & 6 & $\begin{array}{c}\text { Depth Control } \\
\text { On Reading }\end{array}$ & 2 & $\begin{array}{c}\text { Process } \\
\text { drawing, } \\
\text { work } \\
\text { instruction, } \\
\text { first piece } \\
\text { inspection }\end{array}$ & $\begin{array}{l}\text { Inprocess } \\
\text { inspection }\end{array}$ & 3 & 36 \\
\hline 18 & $\begin{array}{c}\text { Deburring, } \\
\text { Cleaning, } \\
\text { Inspection, } \\
\text { Oiling, } \\
\text { Packing }\end{array}$ & $\begin{array}{l}\text { Dust \& Rust } \\
\text { Inside }\end{array}$ & $\begin{array}{c}\text { Functional } \\
\text { problem at } \\
\text { customer end }\end{array}$ & 6 & $\begin{array}{l}\text { Improper } \\
\text { Cleaning }\end{array}$ & 2 & $\begin{array}{c}\text { work } \\
\text { Instruction }\end{array}$ & $\begin{array}{c}\text { Inprocess } \\
\text { inspection } \\
\text { \& pre- } \\
\text { dispatch } \\
\text { inspection }\end{array}$ & 3 & 36 \\
\hline
\end{tabular}

\section{CONCLUSION}

FMEA provides a discipline/methodology for documenting this analysis for future use and continuous process improvement. It is a systematic approach to the analysis, definition, estimation, and evaluation of risks. Following a standard setup procedure will reduce setup time and improve part accuracy thereby increasing the quality and efficiency of processes. Many measures like standard operating procedures, Master piece of Correct Depth is Provide for Setting, Inprocess inspection, process drawing, and first piece inspection. FMEA analysis may easily help in improving the efficiency of the manufacturing process and quality of product thus decreasing the number of defective products and saving of rework cost and time. For each specific process the preventions suggested in the table can considerably decrease the loss to the manufacturing industry in terms of both money and time.

\section{REFERENCES}

[1] A. A. Nannikar, D. N. Raut, M. Chanmanwar, S. B. Kamble and D. B. Patil, "FMEA for Manufacturing and Assembly Process", International Conference on Technology and Business Management, pp. 26-28, March 2012.

[2] André Segismundo, Paulo Augusto Cauchick Miguel, "Failure mode and effects analysis (FMEA) in the context of risk management in new product development: A case study in an automotive company", International Journal of Quality \& Reliability Management, Volume 25 Issue 9, pp.899 - 912, 2008.

[3] Arabian-Hoseynabadi, H. and Oraee, H. and Tavner, P. J. "Failure Modes and Effects Analysis (FMEA) for wind turbines”, International journal of electrical power and energy systems, Volume 32, Issue 7, pp. 817-824, 2010.

[4] ArunChauhan, Raj Kamal Malik, Gaurav Sharma, MukeshVerma, "Performance Evaluation of Casting Industry by FMEA - A Case Study”, International Journal of Mechanical Engineering Applications Research, Volume 2, Issue 2, pp. 113-121, 2011.
[5] Carl S. Carlson, "Understanding and applying the fundamental of FMEAs”, IEEE, January 2014.

[6] Dr. D.R.Prajapati, "Application of FMEA in Casting Industries: A case study”, UdyogPragati, vol.35, Issue 4, pp. 6-14,December 2011.

[7] Ioannis S. Arvanitoyannis and Theodoros H. Varzakas, "Application of ISO 22000 and failure mode and effect analysis [FMEA] for industrial processing of salmon: A case study”, Critical reviews in Food science and Nutrition, Volume 48, pp. 411-429,2008.

[8] K.G. Johnson and M.K.Khan, "A study into the use of the process failure mode and effects analysis (PFMEA) in the automotive industry in the UK", Journal of Materials Processing Technology, Volume 139, pp. 348-356, 2003.

[9] M. Dudek-Burlikowska, "Application of FMEA method in enterprise focused on quality”, Journal of Achievements in Materials and Manufacturing Engineering, Volume 45, Issue 1, pp. 89-102, March 2011.

[10] Namdari M. and rafiw, "Using the FMEA method to Optimize fuel consumption in Tillage by Moldboard Plow", International Journal Of Applied Engineering Research, Volume 1, Issue 4, pp. 734-742, 2011.

[11] Ping-Shun Chen and Ming-Tsung Wu, “A modified failure mode and effects analysis method for supplier selection problems in the supply chain risk environment: A case study”, Computers \& Industrial Engineering, Issue 66, pp. 634-642, 2013.

[12] R.S.Mhetre and R.J.Dhake, "Using Failure Mode Effect Analysis In Precision Sheet Metal Parts Manufacturing Company”, International Journal Of Applied Sciences And Engineering Research, Volume 1, Issue 2, pp.302-311, 2012.

[13] Rakesh.RBobinCherian Jos and George Mathew, "FMEA Analysis

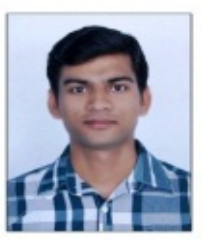
for Reducing Breakdowns of a Sub System in the Life Care Product Manufacturing Industry”, International Journal of Engineering Science and Innovative Technology (IJESIT) Volume 2, Issue 2, pp. 218-225, March 2013.

[14] Sheng HsienTeng and Shin Yann Ho, "Failure Mode and Effects Analysis- An integrated approach for product design and process control”, International journal of quality \& reliability management, volume 13, Issue 5, pp. 8-26, 1996.

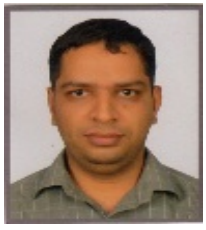
Anand K. Joshi, "Failure mode and effect analysis: A tool to enhance quality in engineering education”, 
International Journal of Engineering, Volume 4, Issue 1, pp. 52-59.

\section{Mr. Tejaskumar Sureshbhai Parsana}

He is Six Sigma Yellow Belt and has completed his B.E. in Mechanical engineering from C U Shah College of Engineering \&Technology in 2012 and M.E. in Industrial Engineering from G H Patel College of Engineering \&Technology in 2014, Gujarat, India.

\section{Mr. MihirThakorbhai Patel}

$\mathrm{He}$ is working as lecturer in Mechanical Engineering Department at Bhailalbhai\&Bhikhbhai Institute of Technology, VallabhVidyanagar, Gujarat. He has more than 11 years of experience in teaching and guiding the projects at Diploma level. He is life member of ISTE. 